\title{
Burgeoning trend of smart clothing: an overview on military use
}

\author{
Aligina Anvitha Sudheshna and Sudha Babel
}

Received: 15.02.2020; Accepted: 23.05.2020

See end of the paper for authors' affiliations Aligina Anvitha Sudheshna Department of Textiles and Apparel Designing, College of Community and Applied Sciences, Maharana Pratap University of Agriculture and Technology, Udaipur (Rajasthan) India

Email : anvithasudheshna@ gmail.com
ABSTRACT : Smart outfit's development started in military field and still remains a main field. Clothing is the first layer of protection and forms an important protective layer in military operation while combats and environmental hazards. Extended Cold weather clothing ensemble, High Altitude Pulmonary Oedema chambers, Anti-G suits, Flame retardant overalls, Submarine Escape Sets, Chemical warfare protection ensemble, liquid cooled garment for protection against hyperthermia etc., are fabricated from variety of technical textiles having special material properties. Technical and smart textiles are used worldwide to provide protection from the hazards of battlefield to the military and paramilitary forces, as 'man behind the machine' is the most important entity in a war theatre. The design of smart cloth is crucial to obtain the best results. This review focuses a collective account of harsh military environment faced by war fighters during War and Peacetime and desired smart textiles to lower the wear and tear due to harsh surroundings and battle menaces.

KEY WORDS: Smart clothing, Technical textiles, Harsh military environment, Phase change materials, Aerogels, Liquid cooled garment, Submarine escape set, Flame retardant fabrics

- HOW TO CITE THIS PAPER : Sudheshna, Aligina Anvitha and Babel, Sudha (2020). Burgeoning trend of smart clothing: an overview on military use. Asian J. Home Sci., 15 (1) : 161-163, DOI: 10.15740/HAS/ AJHS/15.1/161-163. Copyright@ 2020: Hind Agri-Horticultural Society. 